\title{
The Genus Conradina (Lamiaceae): A Review
}

\author{
Noura S. Dosoky ${ }^{1}$ and William N. Setzer ${ }^{1,2, *}$ \\ 1 Aromatic Plant Research Center, 615 St. George Square Court, Suite 300, Winston-Salem, NC 27103, USA; \\ ndosoky@aromaticplant.org \\ 2 Department of Chemistry, University of Alabama in Huntsville, Huntsville, AL 35899, USA \\ * Correspondence: wsetzer@chemistry.uah.edu; Tel.: +1-256-824-6519
}

Received: 24 February 2018; Accepted: 10 March 2018; Published: 11 March 2018

\begin{abstract}
Conradina (Lamiaceae) is a small genus of native United States (US) species limited to Florida, Alabama, Mississippi, Tennessee and Kentucky. Three species of Conradina are federally listed as endangered and one is threatened while two are candidates for listing as endangered. The purpose of the present review is to highlight the recent advances in current knowledge on Conradina species and to compile reports of chemical constituents that characterize and differentiate between Conradina species.
\end{abstract}

Keywords: Conradina; essential oil; ursolic acid; cytotoxicity; antimicrobial; antileishmanial; phylogenetic analysis

\section{Introduction}

Conradina A. Gray (Lamiaceae) is a small genus of morphologically distinctive, narrow-leaved, minty-aromatic shrubs endemic to the southeastern United States of America (USA) [1]. It consists of six to nine US native species. According to the Plant List database [2] and Integrated Taxonomic Information Species (ITIS), the acceptable number of species for the genus is only six (Conradina canescens A. Gray, C. cygniflora C.E. Edwards, Judd, Ionta \& Herring, C. etonia Kral \& McCartney, C. glabra Shinners, C. grandiflora Small and C. verticillata Jennison) while C. brevifolia Shinners, C. montana Small and C. puberula Small are considered synonyms of other species. The Missouri Botanical Garden, however, lists nine distinct species [3]. Conradina species are characterized by very dense hairs on their lower leaf surfaces and by a sharply bent corolla tube in the flowers [1,4]. Asa Gray established the genus Conradina in 1870, named for the American botanist Solomon White Conrad [5]. Conradina species grow well in xeric habitats with well-drained sandy soils. It is thought that Conradina may be a pioneer species in disturbed areas since it has the ability to colonize xeric disturbed habitats [1,5].

Each species of Conradina occupies a separate geographical region [1,6]. Five of the species are endemic to Florida, one is native to west Florida, south Alabama, and south Mississippi, and one is endemic to north-central Tennessee and Kentucky (Figure 1). Due to habitat destruction from residential, commercial, and agricultural land conversions and their very restricted distribution, three of these species are on the United States Fish and Wildlife Service (USFWS) federal list as endangered (Conradina brevifolia, C. glabra, and C. etonia) [5], one as threatened (C. verticillata) [6] and two species are considered candidates for listing as endangered (C. grandiflora and C. cygniflora).

The aim of the present review is to summarize the literature in order to document secondary metabolites that characterize and differentiate between Conradina species. We shall also assess the reported biological activities of Conradina species, with particular focus on their phylogenetic affinities and anti-microbial, anti-leishmanial and cytotoxic properties. 


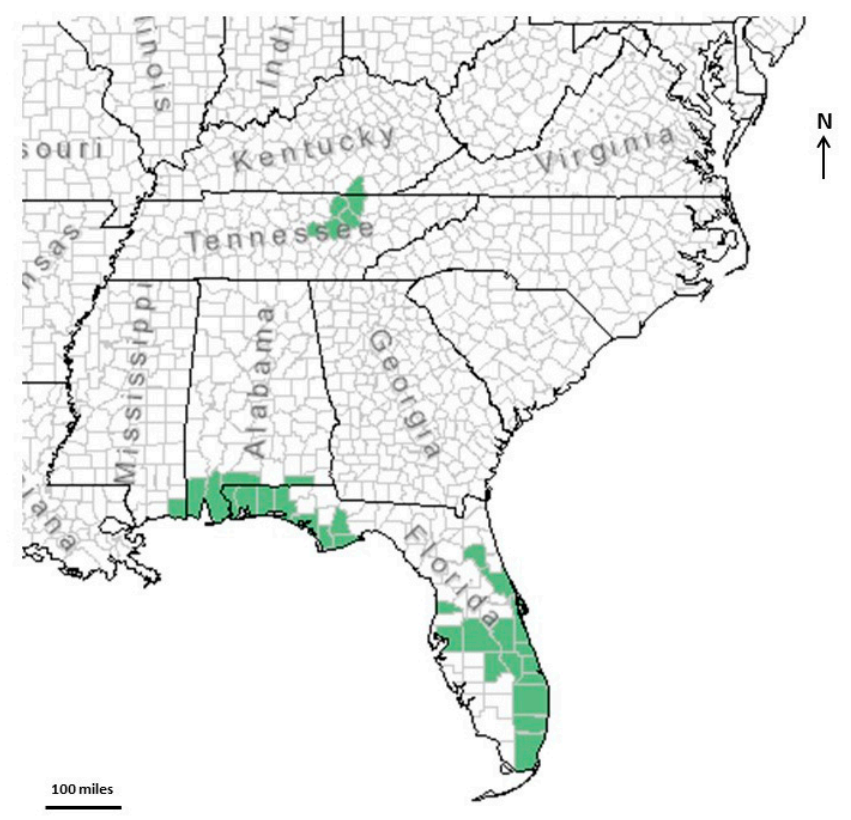

Figure 1. Locations of known populations of Conradina species.

\section{Description}

Conradina represents a group of evergreen, compact, perennial shrubs with virgate branches. Leaves are aromatic and needle-like with narrow, entire, revolute leaf-blades. Flowers are solitary or in a group of few in axillary cymes. The calyx is two-lipped; the lower lip has two long, narrow lobes while the upper lip has three short broad lobes. Corolla is white to purple in color, two-lipped; the lower lip has three lobes and usually dotted while the upper lip is erect and slightly concave.

Conradina canescens A. Gray (false rosemary) is the only species of this genus that is relatively common in its range and the most morphologically variable (Table 1). It is native to a small area of west Florida and south Alabama and southern parts of Mississippi [7]. It occurs on sunny, dry sand soils on coastal dunes, in sand scrubs and in dry longleaf pineland ecosystems. It shows tolerance for the heat and humidity of the Southeast and is considered a drought-tolerant landscape plant that grows best in lean, sandy soils [8]. C. canescens is one of the indicator species for wooded dunes [9] and is an excellent candidate for restoration of coastal areas. It can be used for beach projects that require planting on the back side of primary dunes, or any side of secondary dunes. It has also been used in gardens as a groundcover as the branches can reach up to $1 \mathrm{~m}$ in spread. False rosemary was easily propagated in the University of Florida Institute of Food and Agricultural Sciences Extension using softwood stem cuttings from terminal shoots taken during the growing season.

Morphologically, C. brevifolia Shinners (short-leaved rosemary) is very similar to C. canescens, differing by its shorter leaves and greater number of flowers per axil, and it is also similar to the endangered C. glabra [1,5]. C. brevifolia was described as a new species by Shinners [4]. Many taxonomic reviews of Conradina have upheld C. brevifolia as a distinct species yet it is taxonomically questionable $[1,6,10,11]$. Some taxonomists are still uncertain that $C$. brevifolia is a true different species and therefore they treat it as a synonym to $C$. canescens. $C$. brevifolia has a very restricted range in the middle of the Lake Wales Ridge in Central Florida [12-14] and has been listed as a federally endangered species in 1993 [5]. Habitat destruction for agricultural and residential purposes is the main threat to this species.

C. etonia Kral \& McCartney (Etonia rosemary) was discovered in the Etonia Scrub in Putnam County, Florida in September 1990 and described as a new species in 1991 [6]. C. etonia is similar to $C$. grandiflora in general appearance and the flowers are large and quite similar but the leaves of C. etonia are broader than C. grandiflora and have clearly visible lateral veins on the lower surface $[1,15]$. 
C. etonia is found in very limited areas of deep white sand scrub dominated by sand pines (Pinus clausa) and scrubby oaks (Quercus spp.) on dry soils. Its entire known range is within a subdivision of Putnam County containing streets and a few residences, which make it the most narrowly distributed species of Conradina [6]. C. etonia was listed as a federally endangered species in July 1993 [5]. The latest survey of Etonia rosemary counted about eight subpopulations on Etonia Creek State Forest containing fewer than 1000 total individuals [16]. The major threats facing C. etonia include habitat loss due to development projects for residential housing, horticultural collection, hurricane damage and invasive species or lack of natural processes, such as fire $[17,18]$. Because $C$. etonia requires light but can tolerate the light shade of openings the in scrub, fire suppression is one of the major limiting factors as it results in over-shading by overstory scrub vegetation rendering the habitat less favorable for C. etonia [18].

C. grandiflora Small (large-flowered rosemary) is endemic to the scrub habitat of Florida's east coast between Daytona Beach and Miami as well as near Orlando and Okeechobee County [5]. A regime of frequent fires benefits $C$. grandiflora because it cannot tolerate shade and requires an open sunny habitat. C. grandiflora is a candidate for listing as an endangered species but of a lower priority than other Conradina species [5]. Loss of the Florida scrub habitat is the major threat to this species.

C. glabra Shinners (Apalachicola rosemary) was described in a sand hill community east of the Apalachicola River in Liberty County, Florida in 1962 [1,4]. This species is very narrowly distributed and restricted to Liberty County, Florida. Out of its seven known locations, six C. glabra subpopulations (artificially divided by the Florida gas transmission pipeline) are remaining, all of which are located on private silvicultural lands and subject to much disturbance. Its other historical locations were converted to pine plantations, and can no longer support this species. Because of homozygosity and inbreeding, many of flowers of C. glabra are male sterile, and the stamens are very malformed [1]. It was added to the federal list of endangered species in $1993[5,19,20]$, primarily due to habitat loss and modification of forestry practices. There is no record of how abundant C. glabra was before its habitat was altered because the silviculture operations began before its discovery.

C. verticillata Jennison (Cumberland rosemary) is the only species of this genus that is not found in Florida. The species was established in 1933 [21]. It is a rare species, existing only as three small subpopulations in Tennessee and one subpopulation in Kentucky [22]. C. verticillata is found only in boulder bars, cobble bars, sand bars and gravel bars in close proximity to rivers on the Cumberland Plateau of north-central Tennessee and southeastern Kentucky [22]. The preferred habitat conditions include open to slightly-shaded area, moderately deep well-drained sandy soil, periodic flooding, and topographic features like narrow channels or depressions on gravel bars. $C$. verticillata is the only species that is triploid $(n=3)$ and accordingly has a lower ability to reproduce and disperse sexually and greatly reduced seed germination rates. The fresh seeds of $C$. verticillata are physiologically dormant and require cold stratification to germinate [23]. It has been on the federal list of threatened species since 1991 [24]. The major threats facing C. verticillata are habitat destruction, general deterioration of water quality, competition and shading by woody plants.

In 2009, analysis of patterns of genetic structure based on microsatellites in Conradina led to the identification of C. cygniflora Edwards, Judd, Ionta \& Herring [25]. C. cygniflora can only be found in Dunns Creek state park in south-central Putnam County, Florida. It occupies nine tightly-clustered sites that probably form around two to four self-sustaining subpopulations. C. cygniflora carries several unique morphological characters that distinguish this species from all other described Conradina species including thin-walled unicellular hairs, epidermis features, and larger calyces. Due to its exceptionally limited geographic distribution and low number of individuals, C. cygniflora is considered a candidate for listing as federally endangered [25].

There is very little information in the literature about $C$. montana and C. puberula. C. montana Small was reported in sandy woods and ravines, Appalachian plateau near Rugby, Tennessee while C. puberula Small was observed in pine-lands, northern Gulf coast region, Florida [26,27]. Some taxonomic discrepancies surround C. montana and C. puberula since some experts treat both species as synonyms of $C$. verticillata and $C$. canescens, respectively. 
Table 1. Morphological characteristics of Conradina species.

\begin{tabular}{|c|c|c|}
\hline Species & Morphological Characteristics & References \\
\hline C. canescens & $\begin{array}{l}\text { Small shrub, up to } 1 \mathrm{~m} \text { high. Leaves are } 7 \text { to } 20 \mathrm{~mm} \text { long, mostly longer than the } \\
\text { internodes. Leaf blades are pubescent on both sides. One to three flowers per axil, } \\
\text { lower corolla-lip 8-10-mm long; lateral lobes longer than wide. Calyx-tube hirsute } \\
\text { or villiou-hirsute. }\end{array}$ & {$[5]$} \\
\hline C. brevifolia ${ }^{a}$ & $\begin{array}{l}\text { Small shrub, up to } 1 \mathrm{~m} \text { high. Leaves are short fleshy } 6.0 \text { to } 8.2 \mathrm{~mm} \text { long, mostly } \\
\text { shorter than the internodes, covered with short downy hairs and many tiny glands } \\
\text { on the upper side. One to six lavender flowers per axil. }\end{array}$ & {$[5,11]$} \\
\hline C. etonia & $\begin{array}{l}\text { Straight slender shrub, about } 1.5 \mathrm{~m} \text { high. Leaves have hairy, veiny, glandular } \\
\text { blades } 1.5-3 \mathrm{~cm} \text { long and 3-9 mm wide with tightly rolled edges. Three to seven } \\
\text { flowers per axil. Pink to lavender in color with darker dotted lower petal. }\end{array}$ & {$[5,15,18]$} \\
\hline C. glabra & $\begin{array}{l}\text { Small shrub, about } 80 \mathrm{~cm} \text { high but some individuals reach up to } 2 \mathrm{~m} \text {. Leaves are } \\
\text { opposite, up to } 1.5 \mathrm{~cm} \text { long, hairless on the upper surface. Two to three flowers per } \\
\text { axil. Corolla is } 1.5-2 \mathrm{~cm} \text { long, white to pale lavender in color with a band of purple } \\
\text { dots on the lower lip. }\end{array}$ & {$[5,19,20]$} \\
\hline C. grandiflora & $\begin{array}{l}\text { Erect shrub, } 1.5-2.0 \mathrm{~m} \text { high, with hairy branches and twigs. Leaves are hairy, } \\
\text { glandular, up to } 1.5 \mathrm{~cm} \text { long. Year-round hairy lavender flowers with darker } \\
\text { lavender spots, lower lip is } 12-15 \mathrm{~mm} \text { long with lateral lobes longer than wide. } \\
\text { This species has the largest flowers of genus Conradina. }\end{array}$ & {$[5]$} \\
\hline C. verticillata & $\begin{array}{l}\text { Erect shrub, } 0.5 \mathrm{~m} \text { high with reclining branches. Leaves are about } 2.5 \mathrm{~cm} \text { long, very } \\
\text { narrow, and arranged in tight bunches that appear as whorls around the stems. } \\
\text { Flowers are } 2.5 \mathrm{~cm} \text { long, purple to white and borne in leaf-like clusters of bracts at } \\
\text { the ends of the stems. }\end{array}$ & [24] \\
\hline C. montana ${ }^{b}$ & $\begin{array}{l}\text { Short shrub less than } 0.5 \mathrm{~m} \text { high with diffuse branches. Leaves are narrowly linear, } \\
5-16 \mathrm{~mm} \text { long. Leaf blades are glabrous on the upper surface. Minute flowers with } \\
\text { corolla } 3.5-4 \mathrm{~mm} \text { long. Calyx-tube hirsutulous. }\end{array}$ & [23] \\
\hline C. puberula ${ }^{a}$ & $\begin{array}{l}\text { Short shrub of about } 0.5 \mathrm{~m} \text { high with numerous slender branches. Leaves are } \\
\text { narrowly linear but strongly revolute and clavate, } 12-20 \mathrm{~mm} \text { long. Calyx-tube } \\
\text { minutely canescent, } 5-7 \mathrm{~mm} \text { long. Flowers appear in racemes of } 2-6 \text { per axil, with } \\
\text { corolla } 4-5 \mathrm{~mm} \text { long. }\end{array}$ & {$[26,27]$} \\
\hline C. cygniflora & $\begin{array}{l}\text { Virgate shrub up to } 1 \mathrm{~m} \text { high, branches are erect to spreading, internodes } 5-43 \mathrm{~mm} \\
\text { long. Leaves persistent, appearing fascicled- verticillate; narrowly obovate, } \\
9-33 \mathrm{~mm} \text { long. The abaxial leaf surface is densely-covered by simple unicellular } \\
\text { hairs. Cymes carry 1-5 subsessile flowers, densely pubescent, } 1.3-12.5 \mathrm{~mm} \text { long. } \\
\text { Large calyx of } 8.5-11 \mathrm{~mm} \text { long; densely covered with simple hairs, upper lip } \\
\text { upcurved, } 3.6-4.4 \mathrm{~mm} \text { long, lower lip } 4.3-5.5 \mathrm{~mm} \text { long. Corolla strongly bilabiate, } \\
\text { 20-29 mm long, lavender, shading to white in throat, with purple spots; abaxial } \\
\text { surface of upper lip darker lavender. }\end{array}$ & [25] \\
\hline
\end{tabular}

\section{Phylogenetic Studies}

Conradina is a member of Lamiaceae and belongs to a clade of New World Mentheae. The closely related genera that share similar morphology and habitat preference with Conradina include Dicerandra spp., Piloblephis spp., Stachydeoma spp., and the woody, southeastern U.S. species of Clinopodium such as C. ashei, C. georgianum, C. coccineum, and C. dentatum [28]. Despite the fact that Conradina species are morphologically distinguishable, there are two problems about species status based on morphology. First, C. brevifolia (endangered species) shares a lot of morphological characteristics with C. canescens (relatively widespread in its range). Second, populations of Conradina in Santa Rosa County, Florida, have morphological characteristics in common with both C. glabra (endangered species) and C. canescens. Due to the endangered status of four Conradina species, it is important to resolve the species relationships, define species limits and elucidate the evolutionary processes in order to help with conservation plans. Conradina was subjected to 
several phylogenetic analyses using four data partitions: plastid DNA, internal transcribed spacer (ITS), and two members of the GapC gene family [29-31]. These analyses did not resolve species relationships in Conradina. In agreement morphological evidence, ITS results supported a monophyletic Conradina while plastid DNA results did not. Some Conradina populations showed moderate levels of inbreeding, but inbreeding does not seem as a major factor. Because previous analyses failed to resolve species relationships separately, combined analyses were carried out but the results still did not resolve the relationships within Conradina. Studies using genotype data from quickly evolving microsatellite loci suggested that both ancient interspecific hybridization and incomplete lineage sorting of ancestral polymorphism have likely occurred in Conradina and that based on the patterns of genetic structure (which corresponds to species bounderies), Conradina species have diverged genetically from one another (nonmonophyly) despite having unique distribution patterns and distinguishing morphological characteristics [31].

\section{Essential Oils and Non-Volatile Components}

\subsection{Essential Oils}

The essential oils obtained from the aerial parts of Conradina spp. are rich in terpenes, terpenic aldehydes and ketones, and terpenic alcohols [32,33]. Terpenes released from Conradina are allelopathic, and are believed to help prevent wildfires [34,35] and to protect against insects [32]. The main components quantified in the essential oils of Conradina species with the respective percentages (\%) are summarized in Table 2. The essential oil of C. cygniflora has not been studied yet. 1,8-Cineole and camphor are the major components of C. canescens, C. brevifolia, C. glabra and C. verticillata [7]. The common components found in all Conradina species (excluding C. cygniflora) share a terpenoid skeleton but vary in cyclization and oxygenation (Figure 2). These common components include 1,8-cineole (bicyclic monoterpene ether), camphor (bicyclic monoterpene ketone), $\alpha$-pinene (bicyclic monoterpene), $\beta$-pinene (bicyclic monoterpene), $\beta$-myrcene (acyclic monoterpene), borneol (bicyclic monoterpene alcohol), sabinene (bicyclic monoterpene), camphene (bicyclic monoterpene), and $\beta$-caryophyllene (bicyclic sesquiterpene).

Table 2. Chemical composition of essential oils of Conradina species.

\begin{tabular}{|c|c|c|c|}
\hline Species & Major Oil Components (\%) & Unique Component(s) & Reference \\
\hline C. brevifolia ${ }^{a}$ & $\begin{array}{l}\text { Camphor }(9.7-17.54 \%) \text { and 1,8-cineole } \\
(1.97-4.86 \%)\end{array}$ & $\alpha$ - and $\beta$-farnesene & [7] \\
\hline C. canescens $^{a}$ & $\begin{array}{l}\text { Camphor }(0.27-23.64 \%), 1,8 \text {-cineole }(0.17-3.34 \%) \text {, } \\
\text { cis-pinocamphone }(0-8.74 \%)\end{array}$ & none & [7] \\
\hline C. canescens $^{b}$ & $\begin{array}{l}\text { 1,8-cineole }(5.2-25.2 \%), \text { camphor }(5.7-8.0 \%) \text {, } \\
\alpha \text {-pinene }(3.2-5.6 \%), p \text {-cymene }(3.3-5.9 \%), \\
\text { cis-pinocamphone }(1.3-5.5 \%), \text { myrtenal } \\
(5.2-8.1 \%), \text { myrtenol }(3.4-9.2 \%), \text { verbenone } \\
(4-4.5 \%), \text { and myrtenyl acetate }(5.0-5.4 \%)\end{array}$ & - & [33] \\
\hline C. etonia ${ }^{a}$ & $\begin{array}{l}\text { Camphor }(30.55-35.65 \%) \text {, limonene }(3.77-6.33 \%) \text {, } \\
\text { camphene }(2.92-3.75 \%) \text {, and } \beta \text {-caryophyllene } \\
(2.95-6.54 \%)\end{array}$ & $\begin{array}{l}\beta \text {-elemene, } 4 \text {-carene and } \\
\alpha \text {-terpineol }\end{array}$ & [32] \\
\hline C. glabra ${ }^{a}$ & $\begin{array}{l}\text { 1,8-cineole }(2.38-7.34 \%) \text { and camphor } \\
(11.78-15.88 \%)\end{array}$ & Dolcymene and bornyl acetate & [7] \\
\hline C. grandiflora ${ }^{a}$ & $\begin{array}{l}\beta \text {-pinene }(4.38-5.81 \%) \text { and } \beta \text {-cubebene } \\
(1.95-6.56 \%)\end{array}$ & Calarene and $\beta$-pinone & {$[7]$} \\
\hline C. verticillata ${ }^{a}$ & $\begin{array}{l}\text { 1,8-cineole }(3.15-3.78 \%) \text { and camphor } \\
(5.81-8.35 \%)\end{array}$ & $\begin{array}{l}\text { Germacrene B and } \\
\text { 2,5,6-trimethyl-1,3,6-heptatriene }\end{array}$ & [7] \\
\hline C. cygniflora & Data not available & $\mathrm{N} / \mathrm{A}$ & $\mathrm{N} / \mathrm{A}$ \\
\hline
\end{tabular}


<smiles>CC(C)C1CCC2(C)CCC1O2</smiles>

1,8-Cineole<smiles>C=C1CC[C@]2(C(C)C)CC12</smiles>

Sabinene<smiles>CC12CCC(CC1=O)C2(C)C</smiles>

Camphor<smiles>CC1(C)C2CCC(C2)C1(C)C</smiles>

Camphene<smiles>CC1=CCC2CC1C2(C)C</smiles>

$\alpha$-Pinene<smiles>C=C1CCC2CC1C2(C)C</smiles>

$\beta$-Pinene<smiles>CC12CCC(C)(C(O)C1)C2(C)C</smiles>

Borneol

Figure 2. Chemical structures of common components found in six species of Conradina.

\subsection{Nonvolatile Components}

Conradina is a reservoir of several important bioactive molecules. However, the chemical studies on Conradina are very limited in number. Six compounds were separated from the chloroform extract of C. canescens leaves (Figure 3): ursolic acid, betulin, $\beta$-amyrin, myrtenic acid, $n$-tetracosane, and oleanolic acid [36]. C. canescens leaves are considered a natural source for ursolic acid [37].

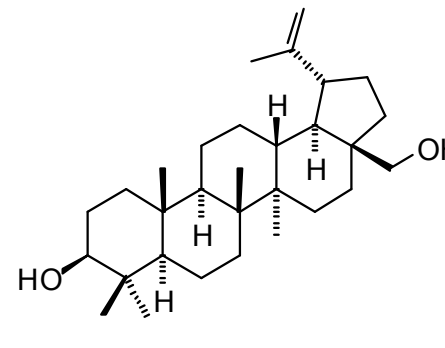

Betulin

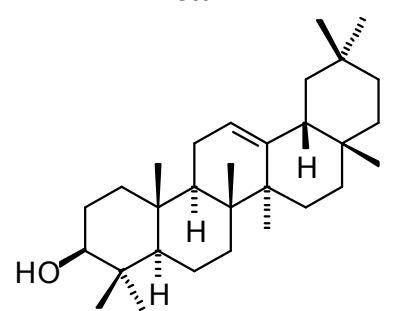

$\beta$-Amyrin

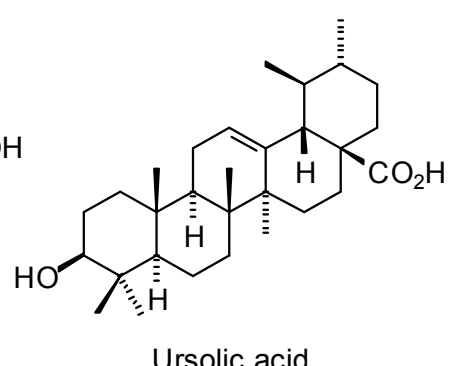

Ursolic acid<smiles>CC1(C)C2CC=C(C(=O)O)C1C2</smiles>

Myrtenic acid

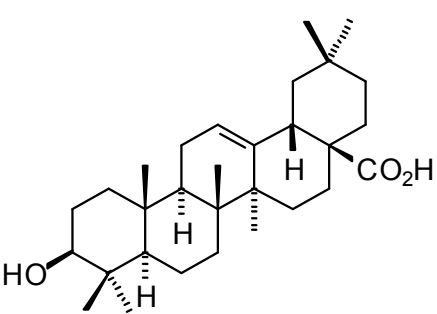

Oleanolic acid<smiles>CCCCCCCCCCCCCCCCCCCCCCCCCC</smiles>

$n$-Tetracosane

Figure 3. Chemical structures of nonvolatile components isolated from Conradina canescens.

\section{Biological Activities}

\subsection{Allelopathic Activity}

The term allelopathy describes the chemical interactions between plants where one plant interferes with the germination and growth of another plant. Allelopathic compounds are thought to enter the surrounding environment via volatilization, leaching with rain, and decomposition of plant litter, thereby inhibiting the growth of competitors or species that may threaten the plant's survival. In this manner, the plant may have an ecological role in its ecosystem by affecting plant spacing, succession, and community composition [35]. Terpenoids, especially monoterpenoids, are considered one of the 14 allelochemical classes $[38,39]$ that play an important role in the interactions between plants $[40,41]$. C. canescens is thought to play a significant ecological role in maintaining a healthy scrub ecosystem by inhibiting the germination of native grasses [42]. It was suggested that by inhibiting germination 
of the grasses, the development of the more fire-prone sand hill ecosystem is prevented, and the scrub ecosystem is maintained [35]. Because detailed knowledge of allelopathic actions in natural plant communities can provide excellent models for new strategies in developing highly selective herbicides, the allelopathic effect of $C$. canescens has been a subject of several studies $[34,35,43]$. Water washes of fresh C. canescens leaves were reported to have strong inhibitory effects on germination and growth of Schizachyrium scoparium [34,43]. The essential oil of $C$. canescens and purified ursolic acid remarkably inhibited the germination of Lactuca sativa and Lolium perenne [37]. The phytotoxic activity of $C$. canescens oil can be attributed to the high concentration of 1,8-cineole which can inhibit the seed germination and seedling growth of lettuce in a dose-dependent manner [44-48] by strongly inhibiting mitochondrial respiration and all stages of mitosis [49]. The presence of significant quantities of ursolic acid suggests that this compound might contribute to the strong allelopathic effect of $C$. canescens $[50,51]$. Ursolic acid is thought to act as a natural detergent by leading water-insoluble monoterpenes to form micelles, rendering them water-soluble, thereby enhancing their ability to leach into rainwater for delivery into the soil $[42,50]$. Ursolic acid helps to co-solubilize the allelopathic monoterpenes in water to be more effective [52].

\subsection{Antibacterial and Antifungal Activity}

The essential oil of $C$. canescens has no antibacterial activity but has a slight antifungal activity against Botrytis cinerea [33] while the crude extracts showed good antifungal activity against Botrytis cinerea [36]. Ursolic acid, the major component in C. canescens leaves was reported to have selective antibacterial activity against $S$. aureus $[36,53]$ while its isomer, oleanolic acid, was active against S. aureus and Pseudomonas aeruginosa. Interestingly, isolated $n$-tetracosane showed antibacterial activity against Staphylococcus aureus and S. epidermidis and antifungal activity against Aspergillus niger and B. cinerea. Isolated myrtenic acid was active against S. aureus, A. niger, B. cinerea and Candida albicans [36].

\subsection{Cytotoxic Activity}

The essential oil of $C$. canescens has no significant in vitro cytotoxic activity against the human breast tumor cell lines MCF-7 and MDA-MB-231 [33]. The crude chloroform extract of C. canescens showed a significant cytotoxic activity against MCF-7 (human breast tumor), MDA-MB-231 (human breast tumor) and 5637 (human bladder tumor) cell lines which is attributed to the presence of betulin and ursolic acid, which when tested individually showed strong effects against all tested cell lines [36].

\subsection{Antileishmanial Activity}

The crude extracts have promising antileishmanial activity against promastigotes and intracellular amastigotes of Leishmania amazonensis. However, the dichloromethane extract had some cytotoxicity on the host cells. The antileishmanial activity of the nonpolar extract was attributed to the presence of ursolic acid and betulin being the major constituents [36].

\section{Conclusions}

This review summarizes the current status, distribution, chemical value and biological studies on genus Conradina. There is still some debate about the exact number of Conradina species as well as the classification/taxonomy of this genus and more studies, especially genetic studies, are still needed. The available information increases the importance of protecting Conradina from extinction. Future studies on this genus may provide valuable information on the mechanism of evolution.

Acknowledgments: This work was carried out as part of the activities of the Aromatic Plant Research Center (APRC, https:/ / aromaticplant.org/). The authors are grateful to dōTERRA International (https://www.doterra. $\mathrm{com} / \mathrm{US} / \mathrm{en}$ ) for financial support of the APRC.

Author Contributions: N.S.D conceived, collected the references, and wrote the initial draft of the review; W.N.S. edited the review. 
Conflicts of Interest: The authors declare no conflicts of interest.

\section{References}

1. Gray, T.C. A Monograph of the Genus Conradina; Vanderbilt University: Nashville, TN, USA, 1965.

2. The Plant List. Available online: http://www.theplantlist.org/tpl1.1/search?q=conradina (accessed on 8 March 2018).

3. The Missouri Botanical Garden. Available online: http://www.tropicos.org $/$ NameSearch.aspx?name= Conradina\&commonname $=($ accessed on 8 March 2018).

4. Shinners, L.H. Synopsis of Conradina (Labiatae). Sida 1962, 1, 84-88.

5. U.S. Fish and Wildlife Service, (USFWS). Endangered and Threatened Wildlife and plants: Endangered or threatened status for five Florida plants. USFWS Fed. Regist. Rules Regul. 1993, 58, 37432-37443.

6. Kral, R.; McCartney, R.B. A new species of Conradina (Lamiaceae) from northeastern peninsular Florida. Sida 1991, 14, 391-398.

7. Peterson, C.L. Analysis of the Essential Oils, Leaf Ultrastructure, and the In Vitro Growth Response of the Mint Genus Conradina; Florida Institute of Technology: Melbourne, FL, USA, 1998.

8. Harrison, M. Groundcovers for the South; Pineapple Press: Sarasota, FL, USA, 2006.

9. Looney, P.B.; Gibson, D.J. The relationship between the soil seed bank and above-ground vegetation of a coastal barrier island. J. Veg. Sci. 1995, 6, 825-836. [CrossRef]

10. Wunderlin, R.P.; Richardson, D.; Hansen, B. Status Report on Conradina brevifolia; U.S. Fish and Wildlife Service: Jacksonville, FL, USA, 1980.

11. Kral, R. A Report on Some Rare, Threatened, or Endangered Forest-Related Vascular Plants of the South; USDA Forest Service: Atlanta, GA, USA, 1983.

12. Christman, S.P.; Judd, W.S. Notes on plants endemic to Florida scrub. Fla. Sci. 1990, 53, 52-73.

13. Christman, S.P. Endemism and Florida's Interior Sand Pine Scrub; Final Report No. GFC-84-101; Florida Game and Fresh Water Fish Commission, Nongame Wildlife Program: Tallahassee, FL, USA, 1988.

14. U.S. Fish and Wildlife Service (USFWS). Short-Leaved Rosemary (Conradina brevifolia): Five-Year Review; USFWS: Atlanta, GA, USA, 2008.

15. U.S. Fish and Wildlife Service (USFWS). Recovery Plan for Etonia rosemary (Conradina etonia); USFWS: Atlanta, GA, USA, 1994.

16. U.S. Fish and Wildlife Service, (USFWS). Conradina etonia, Five-Year Review; USFWS: Atlanta, GA, USA, 2007.

17. Peterson, C.L.; Weigel, R.C. In vitro propagation of Conradina etonia. Fla. Sci. 2002, 65, 201-207.

18. U.S. Fish and Wildlife Service, (USFWS). Etonia rosemary (Conradina etonia); USFWS: Atlanta, GA, USA, 2005.

19. U.S. Fish and Wildlife Service, (USFWS). Recovery Plan for Apalachicola rosemary (Conradina glabra); USFWS: Atlanta, GA, USA, 1994.

20. U.S. Fish and Wildlife Service, (USFWS). Conradina glabra (Apalachicola rosemary): Five-Year Review; USFWS: Atlanta, GA, USA, 2009.

21. Jennison, H.M. A new species of Conradina from Tennessee. J. Elisha Mitchell Sci. Soc. 1933, 48, 268-269.

22. U.S. Fish and Wildlife Service, (USFWS). Recovery Plan for Nineteen Central Florida Scrub and High Pineland Plants (Revised); USFWS: Atlanta, GA, USA, 1996.

23. Albrecht, M.A.; Penagos, J.C.Z. Seed germination ecology of three imperiled plants of rock outcrops in the southeastern United States. J. Torrey Bot. Soc. 2012, 139, 86-95. [CrossRef]

24. U.S. Fish and Wildlife Service, (USFWS). Endangered and Threatened Wildlife and plants: Conradina verticillata (Cumberland rosemary) determined to be threatened. USFWS Fed. Regist. Rules Regul. 1991, 56, 60937-60941.

25. Edwards, C.E.; Judd, S.; Ionta, G.M.; Herring, B. Using population genetic data as a tool to identify new species: Conradina cygniflora (Lamiaceae), a new, endangered species from Florida. Syst. Bot. 2009, 34, 747-759. [CrossRef]

26. Small, J.K. Manual of the Southeastern Flora; The University of North Carolina Press: Chapel Hill, NC, USA, 1933.

27. Small, J.K. Studies in the botany of the Southeastern United States-XIV. Bull. Torrey Bot. Club 1898, 25, 469-484. [CrossRef] 
28. Trusty, J.L.; Olmstead, R.G.; Bogler, D.J.; Guerra, A.S.; Ortega, J.F. Using molecular data to test a biogeographic connection of the Macaronesian genus Bystropogon (Lamiaceae) to the New World: A case of conflicting phylogenies. Syst. Bot. 2014, 29, 702-715. [CrossRef]

29. Edwards, C.E.; Soltis, D.E.; Soltis, P.S. Molecular phylogeny of Conradina and other scrub mints (Lamiaceae) from the southeastern USA: Evidence for hybridization in pleistocene refugia? Syst. Bot. 2006, 31, 193-207. [CrossRef]

30. Edwards, C.E.; Lefkowitz, D.; Soltis, D.; Soltis, P. Phylogeny of Conradina and related Southeastern scrub mints (Lamiaceae) based on GapC gene sequences. Int. J. Plant Sci. 2008, 169, 579-594. [CrossRef]

31. Edwards, C.E.; Soltis, D.E.; Soltis, P.S. Using patterns of genetic structure based on microsatellite loci to test hypotheses of current hybridization, ancient hybridization and incomplete lineage sorting in Conradina (Lamiaceae). Mol. Ecol. 2008, 17, 5157-5174. [CrossRef] [PubMed]

32. Quinn, B.P.; Bernier, U.R.; Booth, M.M. Identification of compounds from Etonia rosemary (Conradina etonia). J. Chromatogr. A 2007, 1160, 306-310. [CrossRef] [PubMed]

33. Dosoky, N.S.; Stewart, C.D.; Setzer, W.N. Identification of essential oil components from Conradina canescens. Am. J. Essent. Oils Nat. Prod. 2014, 2, 24-28.

34. Williamson, G.B.; Fischer, N.H.; Richardson, D.R.; de la Peña, A. Chemical inhibition of fire-prone grasses by fire-sensitive shrub, Conradina canescens. J. Chem. Ecol. 1989, 15, 1567-1577. [CrossRef] [PubMed]

35. Fischer, N.H.; Williamson, G.B.; Weidenhamer, J.D.; Richardson, D.R. In search of allelopathy in the Florida scrub: The role of terpenoids. J. Chem. Ecol. 1994, 20, 1355-1380. [CrossRef] [PubMed]

36. Dosoky, N.S.; Moriarity, D.M.; Setzer, W.N. Phytochemical and biological investigations of Conradina canescens Gray. Nat. Prod. Commun. 2016, 11, 25-28. [PubMed]

37. Dosoky, N.S. Isolation and Identification of Bioactive Compounds from Conradina canescens Gray; University of Alabama in Huntsville: Huntsville, AL, USA, 2015.

38. Rice, E.L. Allelopathy, 2nd ed.; Academic Press: Orlando, FL, USA, 1984.

39. Macias, F.A.; Molinillo, J.M.G.; Varela, R.M.; Galindo, J.C.G. Allelopathy-a natural alternative for weed control. Pest Manag. Sci. 2007, 63, 327-348. [CrossRef] [PubMed]

40. Khan, M.A.; Ungar, I.A. The effect of salinity and temperature on the germination of polymorphic seeds and growth of Atriplex triangularis Willd. Am. J. Bot. 1984, 71, 481-489. [CrossRef]

41. Muller, W.H.; Muller, C.H. Volatile growth inhibitors produced by Salvia species. Bull. Torrey Bot. Club 1964, 91, 327-330. [CrossRef]

42. De la Peña, A.C. Terpenoids from Conradina canescens (Labiatae) with Possible Allelopathic Activity; Louisiana State University: Baton Rouge, LA, USA, 1985.

43. Fischer, N.H.; Tanrisever, N.; Williamson, G.B. Allelopathy in the Florida scrub community as a model for natural herbicide actions. In Biologically Active Natural Products: Potential Use in Agriculture; Cutler, H.G., Ed.; American Chemical Society: Washington, DC, USA, 1988.

44. Qiu, X.; Yu, S.; Wang, Y.; Fang, B.; Cai, C.; Liu, S. Identification and allelopathic effects of 1,8-cineole from Eucalyptus urophylla on lettuce. Allelopath. J. 2010, 26, 255-264.

45. Nishida, N.; Tamotsu, S.; Nagata, N.; Saito, C.; Sakai, A. Allelopathic effects of volatile monoterpenoids produced by Salvia leucophylla: Inhibition of cell proliferation and DNA synthesis in the root apical meristem of Brassica campestris seedlings. J. Chem. Ecol. 2005, 31, 1187-1203. [CrossRef] [PubMed]

46. Zunino, M.P.; Zygadlo, J.A. Effect of monoterpenes on lipid oxidation in maize. Planta 2004, 219, 303-309. [PubMed]

47. Singh, H.P.; Batish, D.R.; Kohli, R.K. Allelopathic effect of two volatile monoterpenes against bill goat weed (Ageratum conyzoides L.). Crop Prot. 2002, 21, 347-350. [CrossRef]

48. Abrahim, D.; Braguini, W.L.; Kelmer-Bracht, A.M.; Ishii-Iwamoto, E.L. Effects of four monoterpenes on germination, primary root growth, and mitochondrial respiration of maize. J. Chem. Ecol. 2000, 26, 611-624. [CrossRef]

49. Macias, F.A.; Galindo, J.C.G.; Molinillo, J.M.G. Allelopathy: Chemistry and Mode of Action of Allelochemicals, 1st ed.; CRC Press: Boca Raton, FL, USA, 2003.

50. Rizvi, S.J. Allelopathy: Basic and Applied Aspects; Springer Science \& Business Media: Dordrecht, The Netherlands, 2012.

51. Szakiel, A.; Grzelak, A.; Dudek, P.; Janiszowska, W. Biosynthesis of oleanolic acid and its glycosides in Calendula officinalis suspension culture. Plant Physiol. Biochem. 2003, 41, 271-275. [CrossRef] 
52. Weidenhamer, J.D.; Macias, F.A.; Fischer, N.H.; Williamson, G.B. Just how insoluble are monoterpenes? J. Chem. Ecol. 1993, 19, 1799-1807. [CrossRef] [PubMed]

53. Wolska, K.I.; Grudniak, A.M.; Fiecek, B.; Kraczkiewicz-Dowjat, A.; Kurek, A. Antibacterial activity of oleanolic and ursolic acids and their derivatives. Cent. Eur. J. Biol. 2010, 5, 543-553. [CrossRef] 